\title{
Preservation Status and Priorities for In Situ Monitoring of the Weapon Sacrifice in Illerup Ådal, Denmark
}

\author{
ANNA K. E. TJELLDÉN \\ Moesgaard Museum, Denmark \\ SøREN M. KRISTIANSEN \\ Aarhus University, Denmark \\ KNUD B. BOTFELDT
}

The Royal Danish Academy of Fine Arts, School of Conservation, Denmark

Excavations of the southern part of a very rich sacrificial bog in Illerup Ådal, Denmark between 1950 and 1985 recovered approximately 15,000 Iron Age artefacts. At the time, 60 per cent of the area was left unexcavated and thousands of objects are now preserved in situ, but the present preservation status has not been investigated for approximately twenty-five years. Extensive in situ monitoring was carried out for one year in order to present a prioritized plan for further monitoring of the unexcavated areas, producing documentation of groundwater table variations, water quality and vegetation in the area. Results show that the remaining artefacts are generally well preserved in a waterlogged and anaerobic environment. However, in the north-eastern part of the bog, the groundwater table is too low even in a year when net precipitation and hydrological conditions were near normal. In the centre of the bog elevated salt concentrations have been measured in the groundwater.

KEYWORDS Iron Age, bog, monitoring, waterlogging, anaerobic environments, Denmark

\section{Introduction}

The European Convention on the preservation of archaeological heritage (European Council, I992) declares the need for implementing measures that secure preservation and maintenance of archaeological artefacts in situ. Due to this declaration, a number 
of in situ monitoring projects have been carried out by the National Museum of Denmark (Gregory et al., 2002; Matthiesen, 2004). Experiences from these studies were implemented at the Danish sacrificial bog in Illerup Ådal, Jutland, a site that holds one of the largest and best-preserved Iron Age weapon sacrifices ever found in Northern Europe.

The sacrificed war material in Illerup Ådal dates back to AD 200-500, and excavations of $c .40$ per cent of the sacrificial area have hitherto revealed approximately I 5,000 artefacts. The artefacts from Illerup are generally very well preserved (Ilkjær, 2000) due to the anaerobic and near neutral environment of the lake and bog sediment containing the sacrifice. Shields, swords, lances, and spears are practically fully preserved, but protein-rich organic materials such as woollen textiles and equestrian equipment made of leather have deteriorated in the burial environment. Such objects are found as partly mineralized fragments only.

In situ preservation requires environmental conditions that are non-aggressive for the buried artefacts. For example, a groundwater level below or very near to the depth of artefact burial is very harmful to in situ preserved metal, since excess amounts of oxygen quickly oxidize metal surfaces and accelerate the deterioration of organic objects caused by micro-organisms. If water is drained from the organic materials the deteriorated parts can collapse. Plants may also pose a threat to weapon sacrifices in sacrificial bogs, as the roots of plants such as the horsetails (Equisetum sp.) or willows reach several metres down into strongly anoxic sediment and can pierce through organic artefacts (Gregory et al., 2002).

The aim was to monitor current preservation conditions at the unexcavated areas of Illerup Ådal in order to evaluate the primary parameters for future in situ investigations and to identify present and possible future threats to the in situ preserved weapon sacrifice.

\section{Materials and methods}

\section{Site description}

Illerup Ådal is situated in central Jutland, Denmark (Figure I). Parts of the sacrificial bog, approximately $60,000 \mathrm{~m}^{2}$, have been left unexcavated for future research, and several thousand objects are expected to be found still in situ (Figure I). Today the excavated area is covered by several small ponds, while a meadow for grazing and bogs cover the unexcavated areas. Groundwater table and environmental conditions have not been monitored since the site was restored after the archaeological excavations ended in 1985 . The artefacts are found at depths varying from I to $3 \mathrm{~m}$ in lake deposited gyttja.

\section{Environmental monitoring}

The estimation of threats and primary monitoring parameters in Illerup Ådal rely on environmental measurements of the water table, analysis of water quality and assessment of vegetation in the area. In October 2009, the northern part of the sacrificial bog was surveyed and the groundwater table was monitored using a grid of nine wells with PE tubing with perforated intakes slightly deeper (I.5-3 $\mathrm{m}$ b.s.) than the artefact layer. Groundwater levels were measured manually twice a month from November 2008 to November 2009 . 


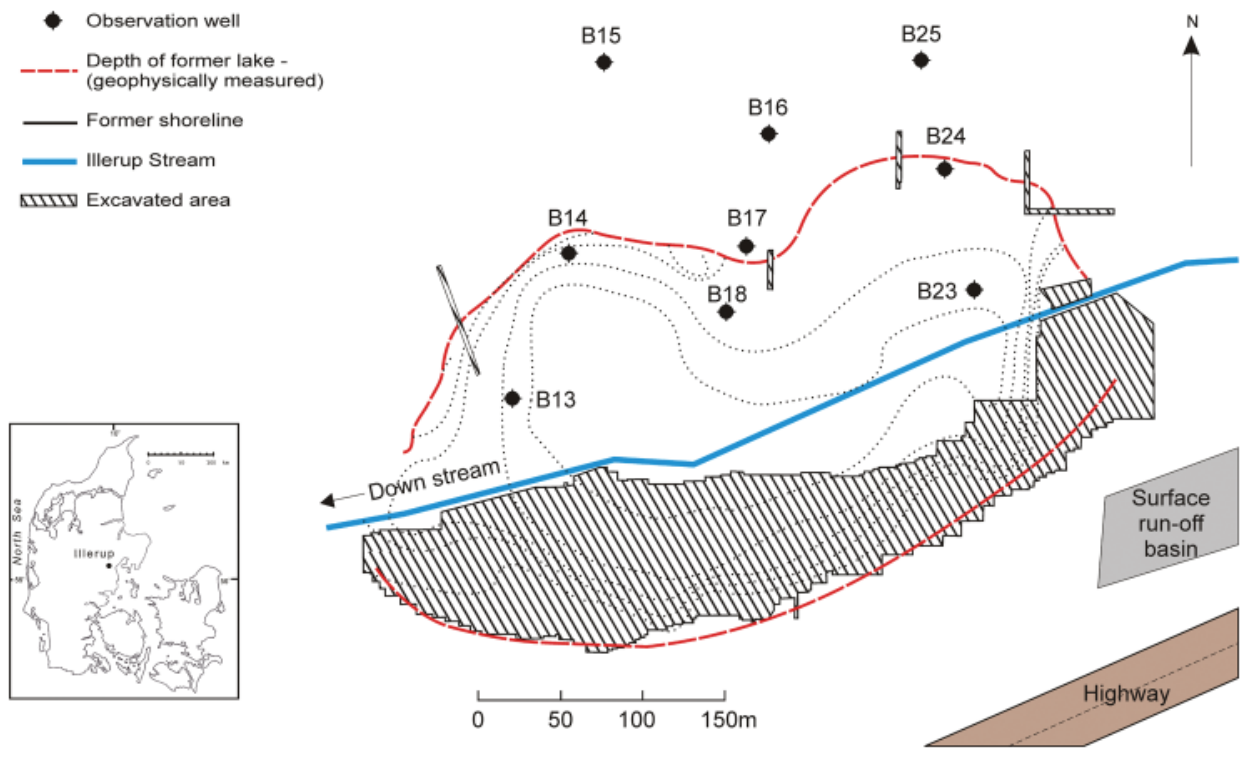

FIGURE 1 Map of the former lake basin at Illerup, Denmark. Positions of the wells are shown. The Illerup stream runs through the sacrificial bog from north-east towards south-west. The inserted map shows the location of Illerup Ådal in Denmark. (Partly redrawn from Ilkjær, 2000.)

The water quality was measured in situ on 28 November 2008 using a flow-through cell, with in-line measurement of $\mathrm{pH}$, electrical conductivity, and redox potential. It was only possible to install an in-line pump (for the abstraction of non-oxidized samples) to three out of nine wells. Due to the very low yield of all wells, in-line flow-through cell readings were carried out every $1 / 2$ minute until no more water was obtainable, and the last recorded value was noted.

The low yields caused relative high redox potentials and presence of $\mathrm{NH}_{4}^{+}$suggesting chemical non-equilibrium of the water samples, and redox sensitive parameters are hence likely to be more reduced due to partial oxidation during sampling. Dissolved Fe data are not reported of the same reason as precipitation was observed during sampling.

Water samples for laboratory analysis were withdrawn on 3 December 2008 from wells $\mathrm{B}_{13}, \mathrm{~B}_{17}$, and $\mathrm{B}_{23}$, along with water from the Illerup stream and the surface water run-off basin. Groundwater samples were collected in acid-rinsed glass bottles, ensuring that as little atmospheric air as possible entered. An extra sample from the run-off basin was taken on 9 January 2009 to investigate the impact of de-icing road salt used nearby. Water samples were stored at $3^{\circ} \mathrm{C}$ and $0.45 \mu \mathrm{m}$ filtered prior to analysis. Concentrations of major cations $\left(\mathrm{NH}_{4}^{+}, \mathrm{Na}^{+}, \mathrm{K}^{+}, \mathrm{Ca}^{2+}\right.$, and $\left.\mathrm{Mg}^{2+}\right)$ and anions $\left(\mathrm{NO}_{3}{ }^{-}, \mathrm{SO}_{4}{ }^{2-}, \mathrm{PO}_{4}{ }^{3-}\right.$, and $\left.\mathrm{Cl}^{-}\right)$were measured.

The vegetation in the unexcavated areas was recorded in October 2009 by an experienced botanist. 

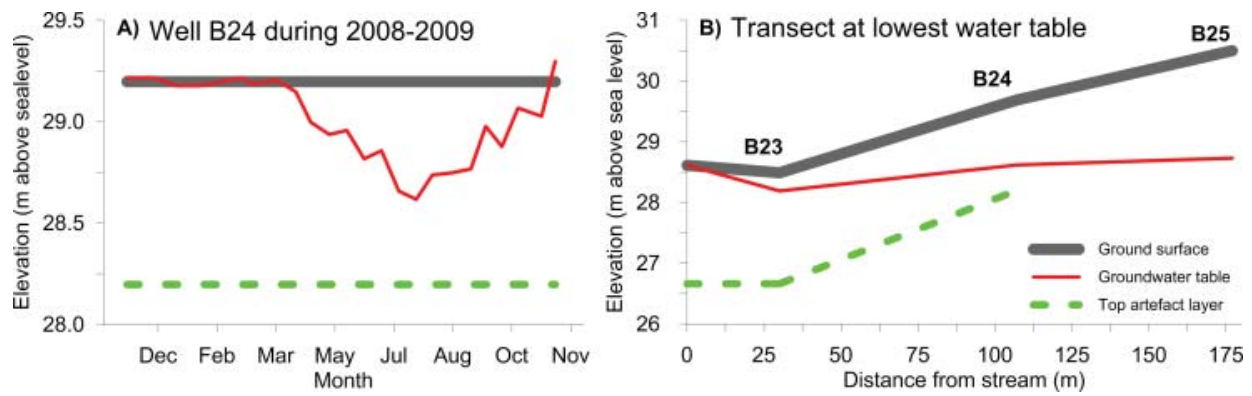

FIGURE 2 Groundwater table fluctuations at well B24 from November 2008 to November 2009 are shown in Figure $2 \mathrm{~A}$; while $2 \mathrm{~B}$ shows a cross-section through the northern part of the sacrificial bog at the time of the lowest water table (19 July 1 2009). The $y$-axis refers to a Danish vertical reference system, i.e. m a.s.l. (DNN).

\section{Results}

Measurements of the groundwater table show that the artefacts were below the groundwater table between November 2008 and November 2009. Figure 2 shows the lowest groundwater level in relation to the artefact layer during the period. For example, at $\mathrm{B}_{24}$ the artefacts are situated approximately $100 \mathrm{~cm}$ below the surface; the minimum groundwater table was $42 \mathrm{~cm}$ above the artefacts and the upper $>60 \mathrm{~cm}$ thick layer of peat was exposed to atmospheric oxygen during the driest summer month. In the summer of 2009 , the other wells had $>64 \mathrm{~cm}$ between the minimum groundwater level and the expected depth of the artefacts.

Water chemistry from the four wells reflected a neutral peat soil with a $\mathrm{pH}$ of approximately $6.5-6.8$ buffered by the gyttja layer rich in carbonate-consisting shells. The excavation in $1975-85$ documented precipitation of vivianite (iron phosphate), which only occurs in a highly reducing environment. The water analysis from 2008 supported this as it produced a very high content of reduced compounds (Tables I and 2). The artefacts therefore lie in an anaerobic, reduced, and high $\mathrm{pH}$ environment. The $\mathrm{Cl}$ concentration in the surface water run-off basin was $150 \mathrm{mg} / \mathrm{l}$ in December 2008 but measurements in January 2009 revealed up to $650 \mathrm{mg} / \mathrm{l}$.

No Horsetails (either Equisetum palustre or Equisetum fluviátile L.) were found at the northern part of the sacrificial bog in Illerup Ådal. However, a larger group of grey willow (Salix cinerea L.) grow right on top of the sacrificial bog, covering an area of $2-400 \mathrm{~m}^{2}$.

TABLE 1

GROUNDWATER CHEMISTRY MEASURED IN SITU AT THE DEPTHS OF ARTEFACT BURIAL IN ILLERUP ÅDAL

\begin{tabular}{lccccc}
\hline Site & Redox potential $[\mathrm{mV}]$ & Oxygen $[\mathrm{mg} / \mathrm{l}]$ & $\mathrm{pH}$ & Conductivity $[\mu \mathrm{S} / \mathrm{cm}]$ & Temperature [Celcius] \\
\hline Well B13 & 181 & 0.95 & 6.54 & 424 & 8.5 \\
Well B17 & 243 & 3.52 & 6.82 & 218 & 7.0 \\
Well B23 & 185 & 0.80 & 6.56 & 220 & 6.2 \\
\hline
\end{tabular}


TABLE 2

MAJOR IONS IN THE GROUNDWATER AT THE DEPTHS OF ARTEFACT BURIAL IN ILLERUP ÅDAL

\begin{tabular}{lccccccccc}
\hline $\begin{array}{l}\text { Parameter } \\
\text { Site }\end{array}$ & $\begin{array}{c}\mathrm{Ca}^{2+} \\
\mathrm{mg} / \mathrm{l}\end{array}$ & $\begin{array}{c}\mathrm{Cl}^{-} \\
\mathrm{mg} / \mathrm{l}\end{array}$ & $\begin{array}{c}\mathrm{K}^{+} \\
\mathrm{mg} / \mathrm{l}\end{array}$ & $\begin{array}{c}\mathrm{Mg}^{2+} \\
\mathrm{mg} / \mathrm{l}\end{array}$ & $\begin{array}{c}\mathrm{Na}^{+} \\
\mathrm{mg} / \mathrm{l}\end{array}$ & $\begin{array}{c}\mathrm{NH}_{4}^{+} \\
\mathrm{mg} / \mathrm{l}\end{array}$ & $\begin{array}{c}\mathrm{NO}^{3-} \\
\mathrm{mg} / \mathrm{l}\end{array}$ & $\begin{array}{c}\mathrm{PO}_{4}^{3-} \\
\mathrm{mg} / \mathrm{l}\end{array}$ & $\begin{array}{c}\mathrm{SO}_{4}^{2-} \\
\mathrm{mg} / \mathrm{l}\end{array}$ \\
\hline Illerup stream & 82.2 & 59 & 3.7 & 5.92 & 31.3 & 146 & 10.5 & 115 & 40.6 \\
Well B23 & 165 & 41.2 & 2.8 & 12.3 & 28.3 & 47.6 & 1.0 & 54 & 1.8 \\
Well B13 & 179 & 110 & 3.7 & 13.6 & 72.4 & 44.2 & $<1$ & 47.8 & $<1$ \\
Well B17 & 158 & 39.9 & 0.9 & 5.62 & 17.2 & 5.26 & 3.3 & 146 & 2.1 \\
$\begin{array}{l}\text { Surface water } \\
\text { run-off basin }\end{array}$ & 38.8 & 150 & 5.6 & 2.74 & 90.6 & 1.09 & 3.3 & 158 & 14.1 \\
\hline
\end{tabular}

*n.d. denotes not determined.

\section{Discussion}

\section{Critical low groundwater levels}

In Illerup Adal, the most critical measurements in relation to the upper layer of the artefacts were measured in the northeastern part of the bog. The lowest measured water table was on I9 July 2009 when the water table at B24 was only $c .40 \mathrm{~cm}$ above the depth of the artefacts. At well $\mathrm{B}_{7} 7$ a relatively low water table was also measured on 5 July; just $64 \mathrm{~cm}$ above the artefacts. A thick unsaturated zone with atmospheric air circulation may cause a slow but steady mineralization of the peat and hence a continuous subsidence of the surface can be expected. Estimates based on a review made by Fanger (I990) on Danish and international experiences suggest a $0.5^{-} \mathrm{I} \mathrm{cm}$ loss of terrain height per year due to mineralization in such geological settings. This is likely to take place in most of the north-eastern part of the area, but this has not been documented yet.

The winter of 2008 had below average rainfall and April 2009 was also dry. However, the summer and autumn of 2009 were unusually wet, and seen as a whole the measured period had a small surplus of precipitation relative to the Danish Metrological normal (I96I-90) (Frich et al., I998). Although Illerup received more rainfall than average, a month long summer drought caused the groundwater table to drop to less than $50 \mathrm{~cm}$ above the artefacts. Detailed investigations in another Danish sacrificial bog at Åmosen, with comparable environmental settings, showed that when the groundwater is $<20 \mathrm{~cm}$ above the artefacts, measureable deteriorations of the organic matter were observed (Matthiesen and Jensen, 2005). Considering the increase in degradation rates of repeated dry-wet cycles (Hopkins, 2004; Williams et al., 2008) this suggests that the groundwater table of the sacrificial bog in Illerup Ådal is too low in the north-eastern part. Future subsidence due to mineralization will enhance this problem.

\section{Chemical preservation status}

The measured level of ammonium in Illerup is high, while nitrate levels are below the detection limit, generally suggesting a reduced environment at the burial depth of the artefacts. High concentrations of dissolved $\mathrm{Fe}^{2+}$ were observed during sampling which 
only occurs in a reduced environment. The $\mathrm{O}_{2}$ contents of 0.80 and $0.95 \mathrm{mg} / \mathrm{l}$ were probably caused by the pumping and do not reflect the actual oxygen content at depth.

In contrast, the measured redox potentials in the groundwater are surprisingly high (average of $203 \mathrm{mV}$ ). However, the redox potential is measured after only $\mathrm{I}^{1} / 2-2 \frac{1}{2}$ minutes of water flow which is too little time to gain a plausible reading from the electrodes, thus reflecting the true groundwater quality. An in situ measurement of the redox potential in these bog sediments with very low hydraulic conductivity would most likely give a more reliable result.

The groundwater composition of well $\mathrm{B}_{13} 3$ differs from the two other analysed wells by an increased electrical conductivity (respectively c. 220 vs. $424 \mu \mathrm{S} / \mathrm{cm}$ ). The reason for this is the elevated sodium chloride content. As long as the artefacts are preserved in a waterlogged environment they are not threatened by chloride ions. However, if the objects are to be excavated and subsequently conserved, the presence of chlorides presents a problem for the preservation of metals and ceramics (Selwyn, 2004; Madsen, I994), wood (McLeod et al., I993) and artefacts of bone, antler, and teeth (Jørgensen and Botfeldt, I986). Chloride contents in the surface water run-off basin upstream showed a high content of I50 to $650 \mathrm{mg} / \mathrm{l}$ during the winter 2008/o9 when de-icing road salt is applied (data not shown). The large content of chloride in the basin and in well $\mathrm{B}_{1} 3$ could correlate with the highway salting southeast of the sacrificial bog. However, as the Illerup stream is situated between $\mathrm{B}_{3} 3$ and the run-off basin this might not be the case, and the elevated chloride content of $\mathrm{B}_{3} 3$ could be due to infiltrating river water enriched in salt from previous de-icing episodes up-stream. This observation is supported by the fact that the groundwater table in the sacrificial bog is lower than the stream during some of the year (see Figure 2) and that the stream thereby regulates the groundwater table of the northern part of the bog.

During excavations in the $1970-80 \mathrm{pH}$ was measured in the surface water and the archaeologists came to the conclusion that $\mathrm{pH}$ in situ was 8-8.5. They found that the artefacts were enclosed in organic rich lake sediments full of carbonate mussels from the prehistoric freshwater lake, thus producing a basic environment. If the organic-rich lake sediment is oxidized due to drainage or archaeological excavation, the sediment will adjust itself to equilibrium between calcium carbonate and the $\mathrm{CO}_{2}$ pressure of soil air. The resulting $\mathrm{pH}$ value is approximately 8 . However, in an anaerobic soil environment with strongly elevated $\mathrm{CO}_{2}$ partial pressures (IO-IOO times ambient air concentrations) carbonates may buffer the bog sediment to a $\mathrm{pH}$ between 6 and 7 only (Matthiesen, 2004). The pH measurements in Illerup carried out in I975-85 were on oxidized soil water and the result was therefore alkalinic. Today well $\mathrm{B}_{\mathrm{I}}$ has slightly raised oxygen content $(3.5 \mathrm{mg} / \mathrm{l})$, while the highest $\mathrm{pH}$ value (6.82) is found here. This indicates de-gassing of $\mathrm{CO}_{2}$ because of stagnated water in the well. The $\mathrm{pH}$ values of the in situ environment indicate a neutral environment around $\mathrm{pH} 6.5^{-6.8}$ in the sacrificial bog, suggesting in situ decomposition at a microscale. Kinetic processes are however likely to be extremely slow due to a buffering effect of the calciumcarbonate rich water surrounding the artefacts. Given the uncertainties regarding in situ $\mathrm{H}^{+}$due to oxidation during measurements, it is of great importance to measure $\mathrm{pH}$ a.o. parameters in situ in future investigations (Caple, 2004). 


\section{Threats from deep-rooted vegetation}

The grey willows (S. cinerea) situated on top of parts of the sacrificial bog area are deep rooted when growing in wet, but still unsaturated soils while the root growth of Salix species are halted within a few weeks after fully flooding occurs (Jackson et al., I997; Talbot et al., I987). The lake sediment in the sacrificial bog had very low hydraulic conductivity (cf. low yields) meaning that the soil is very impermeable, and thus lowering of groundwater tables only slowly will affect subsoils. However, the existence of Salix species could be very problematic in relation to in situ buried artefacts if the sediment overlying the burial depth is not permanently fully waterlogged.

\section{Conclusion}

The presented preliminary in situ investigations of the northern part of the sacrificial bog in Illerup show a generally positive image of the preservation conditions for the remaining weapon sacrifice. However there are circumstances that could harm the artefacts, now or in the future (Figure 3).

A critical low groundwater table was measured in the north-eastern part of the sacrificial bog and it is recommended that the water table is raised here to prevent any risk of oxidation. An area of grey willow grows right on top of the sacrificial bog thus endangering the archaeological artefacts, particularly those made of organic material, and it is recommended that the shrubs are cleared. Measurements of the water quality showed that the water in well $\mathrm{B}_{I_{3}}$ was enriched in $\mathrm{Cl}$, which is probably caused by seepage of de-icing salts from the surface water of up-stream run-off

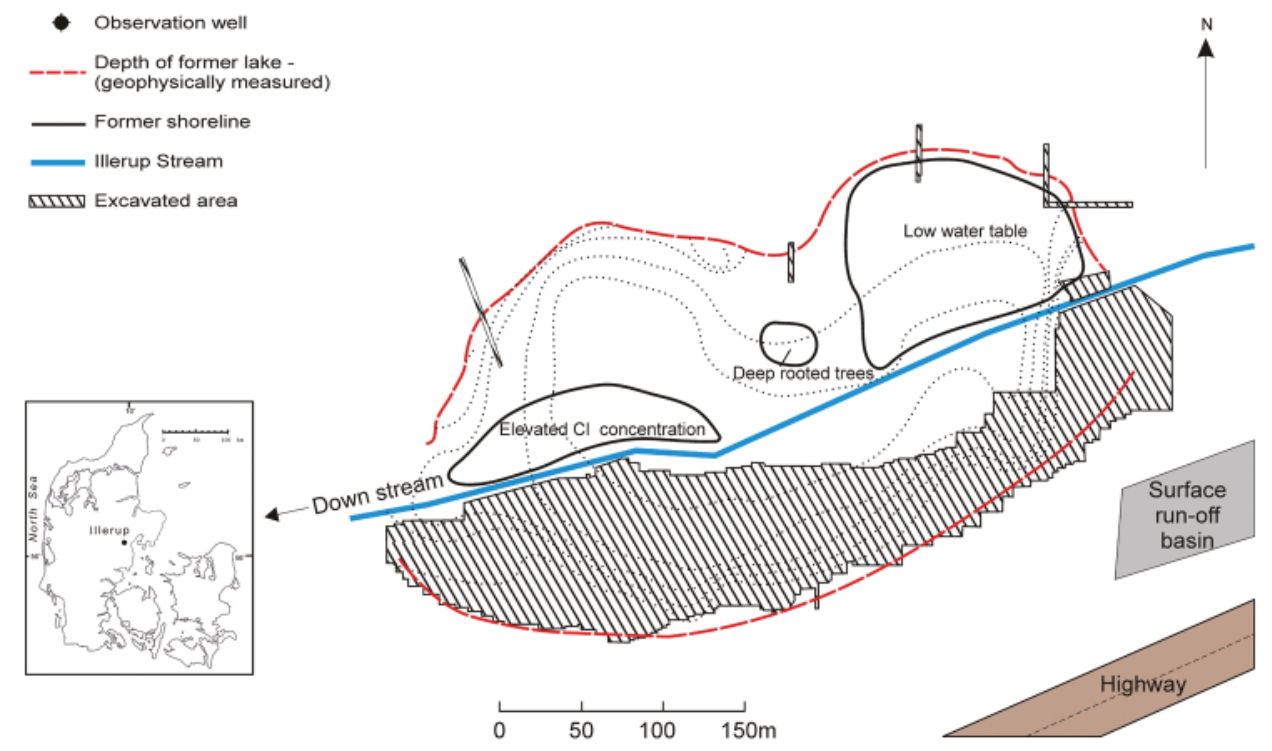

FIGURE 3 Current, possible threats to the unexcavated sacrificial bog in Illerup Ådal. (Partly redrawn from Ilkjær, 2000.) 
basins. It is recommended that future monitoring focuses on possible changes of the chloride content in the wells located near the stream.

\section{Future monitoring}

Recommendations for future monitoring of in situ preservation of the artefacts in Illerup Ådal are as follows:

I) A longer period of monitoring encompassing effects of extreme weather conditions such as a long, dry summer.

2) More targeted monitoring concentrated on the artefact layer throughout the northern part of the bog.

3) Further in situ measurements of soil chemistry and monitoring of the groundwater table by data loggers.

4) Studies of current speed and type of deterioration by introducing test materials in the artefact layer.

5) Biannual monitoring of the vegetation to combat any invading deep-rooted plants.

\section{Acknowledgements}

We would like to thank Jørgen Ilkjær for answering many questions regarding the excavation in $1975-85$ and for assisting with slides, reports, and geological maps of the sacrificial bog. We greatly acknowledge Henning Matthiesen, Hans Huisman, Rune H. Kristiansen, and Bent Aaby for their time and assistance with various aspects of the study. Also skilled technical help from Ruth S. Nielsen and Lars Thomsen is acknowledged. We would like to thank the Royal Danish Academy of Fine Arts, School of Conservation in Copenhagen, the Fondation Idella, and the Augustinus Fonden for financial support. Finally, for the comments of the two anonymous reviewers, whose comments help improve the article.

\section{Bibliography}

Aaby, B. 20I0. Discussion on plants in relation to in situ preservation. (Personal communication, I8 February 2010).

Caple, C., 2004. Towards a Benign Reburial Context: The Chemistry of the Burial Environment. Conservation and Management of Archaeological Sites, 6(3 and 4): I55-65.

European Council, I992. Article 4 \$ii, Council of Europe 1992.

Fanger, K., I990. Sætning af organiske jorder efter dræning. Master thesis I990, Royal Veterinary and Agricultural University of Denmark, I36 pp.

Frich, P., Rosenørn, S., Madsen, H., and Jensen, J.J . I997. Observed Precipitation in Denmark, I96I-90. Danish Metrological Institute, Technical report 97-8. $40 \mathrm{pp}$.

Gregory, D., Matthiesen, H. and Bjørdal, C. 2002. In Situ Preservation of Artefacts in Nydam Mose: Studies into Environmental Monitoring and the Deterioration of Wooden Artefacts. Proceedings of the $8^{\text {th }}$ ICOM Group on Wet Organic Archaeological Materials Conference. Stockholm, II-I5 June, pp. 213-23.

Hopkins, D. W., 2004. Relevance of Soil Biology and Fertility Research to Archaeological Preservation by Reburial. Conservation and Management of Archaeological Sites, 6(3 and 4): 167-75.

Ilkjær, J., 2000. Illerup Ådal - et arkæologisk tryllespejl. Jysk Arkœologisk Selskab 200o, Moesgård Museum. Aarhus: Aarhus University, pp. I-I5I. 
Jackson, M. B. and Attwood, P. A. I997. Roots of willow (Salix viminalis L.) Show Marked Tolerance to Oxygen Shortage in Flooded Soils and in Solution Culture. Plant and Soil, I87: 37-45.

Jørgensen, G. and Botfeldt, K. B. I986. Knogler, tak, tcender, skaller og hornmaterialer. Struktur, nedbrydning og konservering. Copenhagen: The Royal Danish Academy of Fine Arts, School of Conservation, 88 p.

Madsen, H. B. I994. Handbook of Field Conservation. The Royal Danish Academy of Fine Arts, School of Conservation, BB. Copenhagen: Grafik, I24 pp.

Matthiesen, H. 2004. In Situ Measurement of Soil pH. Journal of Archaeological Science, 3I: I373-8I.

Matthiesen, H. and Jensen, P. 2005. Bevaring i Åmosen - hvor vådt er vådt nok?. In: Kultuarv i Naturpark Amosen-Tissø. Special-Trykkeriet Viborg, 2005, pp. 43-52.

McLeod, I. D., Mardikian, P., and Richards, V. L. I993. Observations on the Extraction of Iron and Chloride from Composite Materials. Proceedings of the $5^{\text {th }}$ ICOM Group on Wet Organic Archaeological Materials Conference. Portland/Maine, I993, pp. I99-209.

Selwyn, L. S. 2004. Overview of Archaeological Iron: The Corrosion Problem, Key Factors Affecting Treatment, and Gaps in Current Knowledge. Proceedings of Metal. National Museum of Australia, 4-8 October 2004, pp. 294-306.

Talbot, J. R., Etherington, J. R., and Bryant, J. A. I987. Comparative Studies of Plant Growth and Distribution in Relation to Waterlogging. XII. Growth, Photosynthetic Capacity and Ion Uptake in Salix caprea and C. cinerea spp. Oliefolia. New Phytologist, I05: 563-74.

Williams, J., Fell, V., Graham, K., Simpson, P., Collins, M., Koon, H., and Griffin, R. 2008. Re-watering of the Iron Age Causeway at Fiskerton, England. In: H. Kars and R. M. van Heeringen, eds. Preserving Archaeological Remains In Situ. Proceedings of the $3^{\text {rd }}$ Conference 7-9 December 2006, Amsterdam. Geoarchaeological and Bioarchaeological Studies, I0: I8I-97.

\section{Notes on contributors}

Anna K. E. Tjelldén is an object conservator with focus on in situ preservation. She is employed at the Department of Conservation and Environmental Archaeology at Moesgård Museum, Denmark.

Correspondence to: Anna K. E. Tjelldén, The Department of Conservation and Environmental Archaeology, Moesgaard Museum, Moesgaard Allé 20, 8270 Højbjerg, Denmark. Email: moesat@hum.au.dk

Søren M. Kristiansen is associate professor at the Department of Earth Sciences, University of Aarhus, and focuses on geochemistry of groundwater, soils, and sediments.

Knud B. Botfeldt is a lecturer in archaeological and natural history conservation at the Royal Danish Academy of Fine Arts, School of Conservation. 